\title{
PESAN NASIONALISME DALAM FILM SANG KIAI
}

\author{
Muhammad Fahrisur Rijal \\ Prodi Ilmu Komunikasi \\ Universitas 17 Agustus 1945 Surabaya \\ fahrisurrijal@gmail.com
}

\begin{abstract}
Nowadays there are lots of educational cinema films that can be used as alternatives as learning media. This is in line with the development of the film industry in Indonesia which is developing rapidly through the film with the theme of the heroism of the kiai. He appreciates that the struggle for Indonesian independence, but here is also present from the ulama 'groups which are focused through diplomacy channels spearheaded by NU scholars and students led by $\mathrm{KH}$ Hasyim Asy'ari. This research was conducted to analyze how the Nationalism messages of students and scholars presented in the film by using the semiotic theory of Roland Barthes and qualitative descriptive methods. The researcher can conclude that the message of nationalism in the film of the kiai always gives the messages of nationalism in various ways in every film scene that is served. In this film through the character KH. Hasyim Asy'ari emphasized the audience to always uphold the aqeedah, fight for nationalism, dare to take risks, contribute to the nation and the state as well as inspire others with the deeds done.
\end{abstract}

Keywords : message, nationalism, semiotics

Abstrak. Saat ini banyak tanyangan film-film bioskop edukatif yang dapat digunakan sebagai alternatif sebagai media pembelajaran. Hal ini sejalan dengan perkembangan dunia perfilman di Indonesia yang berkembang pesat melalui Film yang bertemakan kepahlawanan Sang Kiai ini mengapresiasikan bahwa perjungan kemerdekaan Indonesia, tetapi disini juga hadir dari kalangan ulama' yang difokuskan melalui jalur diplomasi yang dipelopori oleh para ulama NU dan santri-santri yang di pimpin oleh KH Hasyim Asy'ari. Penelitian ini dilakukan untuk menganalisa bagaimana pesan Nasionalisme dari santri dan kiai yang tersaji dalam film dengan menggunakan teori semiotik Roland Barthes dan metode deskriptif kualitatif. Peneliti dapat menyimpulkan bahwa pesan nasionalisme dalam film sang kiai selalu memberikan pesan-pesan nasionalisme dengan bermacam cara dalam setiap adegan film yang di suguhkan. Dalam film ini melalui karakter KH. Hasyim Asy'ari menekankan kepada penonton untuk selalu memegang teguh aqidah, memperjuangkan nasionalisme, berani mengambil resiko, berkontribusi untuk bangsa dan negara juga menginspirasi orang lain dengan perbuatan yang dilakukan.

Kata kunci: pesan, nasionalisme, semiotik

\section{Pendahuluan}

Melalui informasi manusia dapat mengetahui peristiwa yang terjadi disekitarnya, memperluas pengetahuan dan wawasan, sekaligus mengetahui perannya dalam masyarakat.dari sekian cara membangkitkan nasionalisme, film dianggap lebih efektif karena setiap gaya, sikap, perilaku tokoh yang di tampilkan 
dalam film dapat ditiru oleh yang menontonnya. Saat ini film tidak hanya menampilkan sebuah cerita fiktif, namun juga banyak dari cerita film yang menampilkan sebuah sejarah dan sebuah realita yang terjadi di dalam masyarakat. di antara banyak yang diangkat di layar perfilman tentang sejarah bangsa Indonesia sendiri.

Mendalami sejarah perjuangan kemerdekaan tidak harus melalui lembaga pendidikan formal seperti sekolah, akan tetapi dapat dipelajari dengan dilakukan melalui penayangan film-film bernuansa nasionalis. Saat ini banyak tanyangan film-film bioskop edukatif yang dapat digunakan sebagai alternatif sebagai media pembelajaran.

Hal ini sejalan dengan perkembangan dunia perfilman di Indonesia yang berkembang pesat dimana film yang sering ditayangkan dilayar televisi, bioskop, maupun di VCD sebagian besar terkandung nilai moral maupun nilai yang positif. beberapa film yang bernuansa nasionalisme yang menampilkan sebuah sejarah perjuangan melawan penjajah dalam merebut kemerdekaan Indonesia yaitu diantaranya film Soekarno, film jendral soedirman, dan film sang kiai dalam film ini menggambarkan potret sejarah perlawanan melawan penjajahan hingga perjuangan proses kemerdekaan Indonesia melawan penjajah, yang tidak terlepas dari tokoh-tokoh para pejuang bangsa diantaranya Ir. Soekarno, Jendral Soedirman dan KH. Hasyim Asy'ari. Film Sang Kiai merupakan film yang di tulis oleh Anggoro Saronto, disutradarai oleh Rako Prijanto dan di produksi oleh Rapi Films. Film ini resmi keluar pada tanggal 30 mei 2013. Film yang bertemakan kepahlawanan ini mengapresiasikan bahwa kemerdekaan Indonesia bukan hany pada para tokoh pejuang bangsa seperti Ir. Soekarno dan Mohammad Hatta saja yang memerdekakan Indonesia, tetapi disini juga hadir dari kalangan ulama' yang difokuskan melalui jalur diplomasi yang dipelopori oleh para ulama NU dan santri-santri yang di pimpin oleh KH Hasyim Asy'ari.

KH. Hasyim Asy'ari. Beliau merupakan sosok santri yang lahir pada tanggal 10 april 1875, di Desa Gedang, Kecamatan Diwek, Kabupaten Jombang, Jawa Timur. Ayahnya bernama Asy'ari sedangkan Ibunya bernama Halimah. Beliau merupakan pendiri Nahdlatul Ulama, organisasi massa islam terbesar di Indonesia saat ini.

KH. Hasyim Asy'ari merupakan sosok yang hidup sederhana dan rajin belajar, ia juga merupakan simbol dari ulama yang nasionalis menjunjung tinggi adat budaya nusantara yang hidupnya dipersembahkan untuk perjuangan kemerdekaan dan kemajuan bangsa.

Film sebagai bagian dari media massa dalam kajian komunikasi masa modern dinilai memiliki pengaruh pada khalayaknya. Munculnya pengaruh itu sesungguhnya sebuah kemungkinan yang sangat tergantung pada proses negosiasi makna oleh khalayak terhadap pesan dari film itu, dan mengacu pada keberhasilan khalayak dalam proses negosiasi makna dari pesan yang disampaikan. Jika negosiasi makna yang dilakukan khalayak tersebut lemah, maka akan semakin besar pengaruh dari tayangan tersebut (McQuaill, 1997). Negosiasi makna merupakan proses transaksional dari komunikasi, dimana komunikasi menerima dan menginterpretasikan makna dari pesan yang diterima sesuai dengan latar belakang sosial budaya yang dimilikinya. 
Film sebagai salah satu bentuk media massa mempunyai peran penting dalam sosialkultral, artistik, politik dan dunia ilmiah. Pemanfaatan film dalam pembelajaran masyarakat ini sebagian di dasari oleh pertimbangan bahwa film mempunyai kemampuan untuk menarik perhatian orang dan sebagian lagi di dasari oleh alasan bahwa film mempunyai kemampuan mengantar pesan secara unik (McQuai, 1997). Selain itu juga film merupakan salah satu media hiburan yang murah dan sederhana.

Menariknya disini hal yang umum biasa kita dengar atau kita tahu hanya para politikus saja yang hanya mempunyai rasa nasionalisme tinggi namun dalam film sang kiai ini mempunyai suguhan berbeda pada sosok lain yang menarik perhatian yaitu KH. Hasyim Asy'ari dan para santrinya digambarkan seorang santri dan kiai yang biasa disebut kaum sarungan yang tidak tau aturan oleh penjajah ini ternyata bisa sangat menjadi nasionalis untuk memperjuangkan kemerdekaan Indonesia dengan mengambil alih negara dari tangan penjajah. Sedikit yang tahu akan hal mengenai pengorbanan para santri dan kiai bahwa mereka juga ikut andil dalam memperjuangkan kemerdekaan dari penjajahan.

Dalam film sosok santri dan kiai berperan besar atas kemerdekaan indonesia dari mulai kiai merestui ijin peperangan melawan penjajah dan juga santri yang ikut terjun dalam peperangan semua memiliki kontribusi dari keduanya itu menunjukan seberapa nasionalis para kaum sarungan itu untuk memerdekakan negaranya.

Pesan tentang moral dapat disampaikan dalam media komunikasi massa, seperti pada media film. Seperti halnya dikemukakan oleh Sumarno (1996:28) bahwa film merupakan karya yang didalamnya mampu mengangkat sebuah realitas rekaan yang nantinya dapat dibandingkan dengan realitas yang terjadi pada masyarakat sebenarnya, sehingga film dapat memebentuk sebuah pemahaman tertentu kepada masyarakat yang nantinya dapat diambil pelajaran yang menghibur.

Oleh karna itu, menjadi menarik untuk menelusuri tanda-tanda yang ada dalam film ini adalah dari sisi nasonalisme yang ada dalam film ini. Dimulai dari lambang, Tanda-tanda yang di suguhkan itu mulai dari bendera hingga isyaratisyarat tertentu yang bisa di artikan dan dikolaborasikan untuk mencapai efek yang di inginkan. Karna film merupakan produk audio dan visual, maka tandatanda itu berupa gambar dan suara. Tanda-tanda tersebut adalah sebuah gambaran tentang sesuatu. Untuk mengetahui hal itu semua, kita dapat menelitinya melalui pendekatan semiotik.

Karena tanda tidak pernah benar- benar mengatakan suatu kebenaran secara keseluruhan (Danesi, 2012: 21). Ia hanya merupakan representasi dan bagaimana suatu hal di presentasikan dan medium yang dipilih untuk melakukan itu bisa sangat berpengaruh bagaimana orang menafsirkannya. Pesan Nasionalisme yang ingin di sampaikan di film ini adalah pentingnya nilai-nilai sejarah masa lalu dimana pendahulu bangsa dalam mempertahankan republik ini melawan penjajah dengan penuh pengorbanan.

Berdasarkan latar belakang diatas penulis tertarik mengambil fokus permasalahan terletak pada santri dan kiai yang menunjukkan sikap mempunyai rasa nasionalisme yang tinggi dalam memperjuangkan kemerdekaan indonesia tidak mengambil dan mengkaji sikap agamis teladan dari santri dan kiai tetapi 
hanya lebih ke Nasionalisme yang dimiliki para kaum sarungan tersebut dengan melawan penjajah dalam filmnya, juga alasan mengambil judul ini ialah karena semangat nasionalismenya yang dipertontonkan juga untuk tanah air yang di tunjukkan para santri dan kiai di dalam film, menariknya dari gambaran film

yang menggambarkan para kaum sarungan ini berani dan tidak kenal takut melawan penjajah karena khalayak hanya tahu seorang santri itu hanya pandai sholat dan mengaji tetapi dalam film sang kiai ini di gambarkan sosok santri dan kiai bagaimana menjalani kehidupan sehari-hari dan menghadapi penjajahan yang mereka terima dan ingin memperjuangkan kemerdekaan tanah airnya.

Masalah dalam film ini mengajarkan tentang bagaimana santri dan kiai menyampaikan pesan- pesan nasionalisme menjadi penggerak (verbal) ke khalayak menjadi nasionalis dalam perjuangan melawan para penjajah dari para sosok kiai terutama yang melakukan pendorong pergerakan pada masyarakat untuk menolak takluk dari penjajahan dengan lambang atau tanda-tanda melalui analisi Semiotik. Maka penulis disini tertarik untuk mengkaji hal tersebut sebagai sebuah penelitian dengan judul : "Pesan Nasionalisme dalam Film Sang Kiai"

\section{Rumusan masalah}

Bagaimana Analisis Semiotik Pesan Nasionalisme dalam Film Sang Kiai ?

\section{Tujuan penelitian}

Penelitian ini bertujuan untuk mengetahui bagaimana Analisis Semiotik Pesan Nasionalisme Dalam Film Sang Kiai.

\section{Metode penelitian}

Jenis penelitian yang digunakan dalam penilitin ini adalah deskriptif kualitatif. Menurut Moleong (2005:4), pendekatan deskriptif kualitatif yaitu pendekatan penelitian dimana data-data yang dikumpulkan berupa kata- kata, gambar-gambar dan bukan angka.

Jadi data yang terkumpul adalah sebuah narasi hasil penjabaran dan pengkajian secara mendalam oleh peneliti. Menurut Kriyantono Penelitian kualitatif tidak mengutamakan besarnya populasi yang akan menjadi objek penelitian, akan tetapi yang lebih ditekankan adalah (kualitas) data, bukan banyaknya (kuantitas) data (2006: 58) Pada penelitian ini penulis menggunakan pendekatan semiotika Roland Barthes, Dalam teorinya Barthes menggunakan tiga hal yang menjadi inti dalam penelitiannya, yakni makna denotatif (penanda), konotatif (petanda) dan mitos (hasil dari kedua pengkontruksian dari tanda tersebut). Sistem pemaknaan kedua ini oleh Barthes disebut dengan konotatif, sedangkan pemaknaan pertama ia sebut denotatif. Sumber Data Dan Tehnis Pengumpulan Data Penelitian yang akan dilakukan melalui metode pengumpulan data dengan metode sebagai berikut :

\section{Metode Observasi}

Metode observasi, yaitu metode yang dilakukan dengan pengamatan langsung obyek penelitian dan sasaran penelitian. Kegiatan keseharian manusia menggunakan pancainderamata sebagai alat bantu utamanya selain pancaindera 
lainnya seperti telinga, penciuman, mulut, dan kulit. Observasi adalah kemampuan seseorang untuk menggunakan pengamatannya melalui hasil kerja panca indera mata serta dibantu dengan pancaindera lainnya (Bungin, 2013:142).

\section{Dokumentasi}

Dokumentasi ini berupa data sekunder seperti scene adegan potongan dari film atau berita di film di media massa yang fungsinya mengulas konten film ini.

\section{Studi Pustaka}

Studi pustaka merupakan salah satu teknik pengumpulan data yang diperoleh dengan mengumpulkan informasi- informasi dari jurnal online, buku dan lain sebagainya. Studi pustaka dalam penelitian ini Selain itu peneliti juga berusaha mencari sumber informasi dari penelitian terdahulu yang relevan dengan penelitian ini. Analisa akan dilakukan pada setiap scene-scene dalam film yang menunjukkan narasi pesan komunikasi dan nasionalisme oleh santri dan kiai. Proses pemaknaan scene disini dengan melalui dua tahap, denotasi, konotasi dan mitos. Adapun langkah analisis data dalam penelitian ini adalah sebagai berikut :

1. Dokumentasi yaitu analisa rekaman DVD, dari adegan scene film sang kiai

2. Mengungkap makna denotasi, konotasi dan mitos dalam scene film sang kiai tersebut

3. Mengambil kesimpulan yang di peroleh

\section{Hasil dan pembahasan}

\section{Pesan "Nasinoalisme yang ditunjukkan"}

Dalam scene tergambar bahwa dari mulainya jepang masuk ke indonesia sebagai sekutu hingga menjadi musuh kawan menjadi lawan dimulainya dari penolakan tentara Nippon kepada masyarakat indonesia yang mengibarkan bendera (merah putih) selain bendera mereka dewa matahari (Denotasi) dan jika melakukan perlawanan kepada peraturan yang telah mereka tetapkan bisa langsung dianggap melakukan pemberontakan kepada Nippon, hukumannya ialah mendapat siksaan dari para bala tentaranya bagi siapapun yang memberontak (Konotasi).

Jadi rasa Nasionalisme yang di miliki kiai dan santri disini tidak pernah luntur dan goyah sedikitpun walaupun harus merasakan di sakiti di asingkan bagaimanapun mereka tetap memegang teguh bahwa mereka tidak ingin di jajah, Jepang menegaskan seluruh rakyat indonesia harus tunduk dan hormat oleh kaisar dewa matahri jepang. Penolakan membungkukan badan terhadap bendera jepang ialah bukti bahwa mereka enggan mengikuti perintah mereka karena mereka tetap berpegangan teguh dengan prinsip nasionalisme mereka sendiri dan tidak ingin mengakaui kedaulatan jepang di tanah lahir mereka sendiri. (Mitos).

\section{Kesimpulan}

\section{Kesimpulan Pesan Nasionalisme melalui penolakan hormat pada bendera jepang}

Berdasarkan pembahasan analisis pada penelitian ini, peneliti dapat menyimpulkan bahwa pesan nasionalisme dalam Film Sang Kiai diatas selalu memberikan pesan- pesan yang bersifat nasionalisme dalam setiap adegan film 
yang di suguhkan. Dalam salah satu scene kiai yang menolak untuk membungkukan badan untuk memberi penghormatan pada bendera dewa matahari (Denotasi) tanpa mengucap kata sedikitpun dan enggan memberi penghormatan hingga akhirnya timbulnya siksaan yang diterima (Konotasi) kiai dari para tentara di kawasan pusat militer mereka, disini kita sebagai penonton film bisa mengambil pelajaran yang sangat berharga pada setiap scene film ini terutama melalui karakter KH. Hasyim Asy'ari menekankan secara tidak langsung kepada penonton dari sikap dan sifat yang tercerminkan untuk selalu memegang teguh aqidah, memperjuangkan nasionalisme, berani mengambil resiko, bahwasannya tunduk dengan kemungkaran ialah bukan cerminan dari ulama khusunya bangsa Indonesia sendiri (Mitos) berkontribusi untuk bangsa dan negara juga menginspirasi orang lain dengan perbuatan yang dilakukan. Film ini menyampaikan pesan pendidikan moral yang sangat bagus dari para kaum sarungan ini untuk khalayak terlebih para generasi penerus selanjutnya.

Setelah mengamati dan menganalisa bab sebelumnya, kesimpulan hasil penelitian ini mengacu pada permasalahan yang ada. Pesan Nasionalisme dalam film sang kiai ini yang disampaikan melalui tokoh-tokoh yang berperan dalam film tersebut, yang tersaji dalam scene adegan dan dialog dalam filmnya.

\section{Saran}

Hasil penelitian ini diharapkan dapat memberikan manfaat dan kontribusi bagi perkembangan ilmu pengetahuan melalui kajian film, serta diharapkan bisa lebih memeberikan kontribusi lagi pada khalayak mengenai pemahaman teori dan metode yang lainnya pada film.

\section{Manfaat Praktis}

Bagi Dunia Perfilman Peneliti berharap dunia perfilman di Indonesia akan lebih maju dan berkembang lagi dengan adanya film-film pendidikan sejarah khusunya tentang tokoh-tokoh kepahlawanan, yang memiliki kualitas yang lebih baik lagi kedepannya dan mengandung banyak pesan-pesan nasionalisme yang dapat diambil pelajarannya.

Juga memberikan wawasan pengetahuan dan memberikan informasi khususnya kepada sesama mahasiswa maupun masyarakat mengenai pentingnya film sejarah kepahlawanan yang lainnya khususnya film Sang Kiai

\section{DAFTAR PUSTAKA}

McQuail, Denis. 1997. Audience Analysis. California: SAGE Publications

Sumarno, Marselli 1996. Dasar- dasar apresiasi film. Jakarta: Gramedia

Danesi, Marcel. 2012. Pesan, tanda dan makna. Yogyakarta: Jalasutra.

Ardianto, Elvinaro. 2007. Filsafat Ilmu Komunikasi. Bandung: Simbiosa Rekatama Media.

West, Richard. 2008. Pengantar Teori Komunikasi. Jakarta: Salemba Humanika

Sobur, Alex. 2006. Analisis Semiotik. Bandung: PT. Remaja Rosdakarya

Moleong, Lexy J. 2013. Metode Penelitian Kualitatif. Edisi Revisi. Bandung : PT. Remaja Rosdakarya.

Kurniawan. 2001. Semiologi Roland Barthes. Magelang: Yayasan Indonesia Tera 
Danim, Sudarwan. 2002. Menjadi Peneliti Kualitatif. Bandung: Pustaka Setia. Winarni. 2003. Komunikasi Massa Suatu Pengantar. Malang: UMM Press.

Mulyana, Dedy. 2005. Komunikasi Suatu Pengantar. Bandung: PT. Remaja Rosdakarya Mulyana, Deddy. 2007. Ilmu Komunikasi: Suatu Pengantar. Bandung: PT. Remaja Rosdakarya.

Kohn, Hans. Nasionalisme Arti dan Sejarahnya, Jakarta: Erlangga 1984

Danesi, Marcel 2010. Pengantar Memahami Semiotika Media. Yogyakarta: Jalasutra

Taniredja, T.. 2013. Konsep Dasar Pendidikan Kewarganegaraan. Yogyakarta: Penerbit Ombak.

A. Sirry, Mun'im, Membendung Militansi Agama: Iman dan Politik dalam Masyarakat Modern, Jakarta: Erlangga, 2003

Tim Penyusun. 2002. Kamus Besar Bahasa Indonesia. Jakarta: Balai Pustaka.

Azwar, Saifuddin. 2007. Metode Penelitian. Yogyakarta: Pustaka Pelajar

Sugiyono. 2011. Metode Penelitian Kuantitatif, Kualitatif dan R\&D.Bandung: Afabeta

Lexy J. Moleong. 2005. metodologi penelitian kualitatif. Bandung: PT. Remaja Rosdakarya.

Bungin, Burhan. 2013. Metode penelitian sosial dan kualitatif. Jakarta: Kencana Prenada Media Group.

Margono. 2003. Metode Penelitian Pendidikan. Jakarta: PT Asdi Mahasatya.

Prijanto, Rako. 2013. Film Snag Kiai. Rapi Films.

Internet :

Meylania, Muhaimah. 2014 "Resensi Film Sang Kiai”. Di akses pada 13 Juni 2020, dari (http://meylaniarifmuhaimah.blogspot.c om/2014/10/tugas-resensi film.html) 08:35 WIB

Azrohal, Hasan. 2015 "Teori Nasionalisme Hans Kohn". Di akses pada 13 Juni 2020, dari (http://azro_el- fib11.web.unair.ac.id/artikel_detail- 150958-UmumTeori\%20Nasionalisme $\%$ 20Hans\%20K ohn.html) 08:45 WIB

Mahardika, Eka. 2013 "Kisah Perjuangan Untuk Agama dan Bangsa" Di akses pada 13 Juni 2020, dari (https://www.kapanlagi.com/showbiz/film/ indonesia/sangkiai-kisah-perjuangan- untuk-agama-dan-bangsa-356977.html) 08:56 WIB 